\title{
Girls Should Bring Lawsuits Everywhere ... Nothing Will Be Corrupted: Pornography as Speech and Product
}

\author{
Marianne Wesson $\dagger$ \\ The Congress finds that . . . it is a tradition of Anglo-American ju- \\ risprudence that victims should be made whole by the ability to re- \\ cover damages for the harm caused them attributable to the miscon- \\ duct of others. \\ Preamble to the Pornography Victims Compensation Act. ${ }^{1}$ \\ Senators considering the measure . . . should look beyond its alleg- \\ edly lofty intent and see it for what it is: a far-reaching, repressive, \\ and probably unconstitutional attempt to stifle protected speech.
}

Washington Post editorial on the Pornography Victims Compensation Act. ${ }^{2}$

At the beginning of his recent anti-censorship memoir Girls Lean Back Everywhere: The Law of Obscenity and the Assault on Genius, obscenity lawyer Edward de Grazia quotes Jane Heap as saying, "[g]irls lean back everywhere, showing lace and silk stockings; wear low-cut sleeveless blouses, breathless bathing suits; men think thoughts and have emotions about these things everywhere-seldom as delicately as Mr. Bloom-and no one is corrupted." $\mathrm{De}$ Grazia then proceeds to castigate (among others)

† Professor of Law and President's Teaching Scholar, University of Colorado. A version of this paper was given at the conference on "Speech, Equality, and Harm: Feminist Legal Perspectives on Pornography and Hate Propaganda" at the University of Chicago Law School, March 5-7, 1993. For suggestions and encouragement I am grateful to the University of Colorado Feminist Work-in-Progress Study Group, especially Marcia Westkott, Glenn George, Alison Jaggar, Carol Glowinsky, Charlotta Hensley, Lori Gruen, Cate Wiley, Rebecca French, and Hardy Long Frank; I also thank Emily Calhoun and Arthur Travers for always helpful criticism and Mary Ann Davitt and Lauren Edelstein for excellent research assistance. But this article is for Anita Hill, although we have never met.

IS 1521, 102d Cong, 1st Sess, in 137 Cong Rec 10554 (July 22, 1991).

2 Editorial, Does Reading Lead to Rape, Washington Post A20 (May 21, 1991).

s Edward De Grazia, Girls Lean Back Everywhere: The Law of Obscenity and the Assault on Genius 10 (Random House, 1992) ("Girls Lean Back"). Heap was a feminist and lesbian who, with her lover Margaret Anderson, ran the Washington Square Bookstore and co-edited the literary magazine The Little Review beginning in 1916. The two women were arrested in 1920 and convicted of publishing obscenity after printing an episode from Ulysses. In that episode, a character "leaned back and her garters were blue to match on account of the transparent and they all saw it and shouted to look . . .." Leonard Bloom is among the observers and as the woman leans farther and farther back to watch the progress of a firework, he "could see her other things too, nainsook knickers, four and eleven ... 
those whom he calls "anti-porn feminists." 4 The Heap quotation is singularly infuriating for it suggests that the romantic pictures conjured up-girls reclining in lacy underwear, beautiful women exposing their bare arms to the sun-are characteristic of the materials that anti-pornography feminists seek to suppress. Furthermore, it hints that those who fight against pornography are paranoid in their belief that such sights will "corrupt" the viewer. I suggest that this ascription of paranoia to the anti-pornography activist may be a bit of projection: it is, after all, persons in Mr. de Grazia's camp who often suggest that any discouragement of the pornography industry will lead to book-burning, empty libraries, and thought control. ${ }^{5} \mathrm{I}$ offer here a practical proposal for anti-pornography activists, to wit: Girls should bring lawsuits everywhere. I will argue that if my proposal is pursued, nothing that a civil libertarian holds dear will be harmed. ${ }^{6}$

Proposals to permit victims of pornography to recover damages from those who create or distribute it are among the most defensible and conservative items on the agenda of anti-pornography activism, yet they are still controversial. ${ }^{7}$ The reasons why these proposals still stir opposition lie partly in history, partly in the politics of the women's movement, partly in the Supreme Court's confused and confusing treatment of First Amendment issues, and partly in the efforts of the pornography industry to protect its privileges and profits. The intersection of these factors has hindered serious feminist consideration of measures that might accomplish many of the goals of the anti-pornography movement. The measure I propose to fill this gap is quite simple: it requires no debate, no lobbying, no legislation. All it requires is the right client and the right lawyer. The right client will be a person (most likely a woman) who has been harmed by an identifiable work or

[and] he could see up high above her knee where no-one ever and she wasn't ashamed and he wasn't either to look in that immodest way . . . ." Id at 9-10. Heap's statement was made to the readers of The Little Review in defense of the decision to publish the chapter. See Jane Heap, Art and the Law, 7 The Little Review 5-6 (No 3 1967).

- De Grazia, Girls Lean Back at 581-86, 609-21.

- Id at xii-xiii.

- I use the phrase to mean one who values arrangements that maximize freedom for the greatest number of persons.

7 See, for example, Maureen Dezell, Bundy's Revenge: Pornography Victim's Compensation Act, New Republic 15 (Mar 9, 1992); James J. Kilpatrick, Alas, Well-Intentioned Pornography Bill Would Accomplish Little of Substance, Atlanta Journal A11 (Aug 26, 1992); A Damaging Remedy for Sex Crimes, NY Times A18 (Apr 13, 1992); Ellen Willis, An Unholy Alliance, Newsday 78 (Feb 25, 1992); Marcia Pally, Don't Blame Pornography for Sexual Violence, St. Petersburg Times 20A (Feb 15, 1992); Wendy Kaminer, Feminists Against the First Amendment, The Atlantic 110 (Nov 1992). 
works of pornography. The right lawyer will be a person (again, most likely a woman) with the resources to bring a lawsuit against the maker or distributors of the material, or both, and the skill to prove the harm, show its foreseeability and its causal link to the pornography, identify the source of the pornography, and overcome the First Amendment objections that are certain to arise.

A brief rehearsal of familiar events may provide some context for this proposal. Pioneering efforts to create remedies for victims of pornography defined both "pornography" and "victim" in an expansive way. In particular, the MacKinnon-Dworkin Model Ordinance and its progeny included in their definition of pornography, "women ... presented in scenarios of degradation, humiliation, injury, torture, shown as filthy or inferior, bleeding, bruised, or hurt in a context that makes these conditions sexual . . . presented dehumanized as sexual objects, things, or commodities ... . [and] presented in postures or positions of sexual submission, servility, or display," if these depictions constitute the "graphic sexually explicit subordination of women." enforcement actions to be brought by "[a]ny woman . . . acting against the subordination of women." If a woman could prove that certain material met the ordinance's definition of pornography, an injunction against the further sale or dissemination of the material could be obtained. ${ }^{10}$

I admire and salute the efforts of MacKinnon, Dworkin, and others who worked tirelessly on the campaign for the ordinances, but their success lay more in reframing the issue of pornography, creating a convincing language for talking about it, and calling attention to its harm, than in securing a remedy. Indeed, the Model Ordinance was held to be unconstitutional under the First Amendment."1

Moreover, even some self-described feminists opposed the ordinances, arguing that they could be used to censor such mainstream speech as the Lina Wertmuller film Swept Away and many

${ }^{8}$ Model Antipornography Civil-Rights Ordinance, reprinted in Andrea Dworkin and Catharine A. MacKinnon, Pornography and Civil Rights: A New Day For Women's Equality 138-39 ("Model Ordinance"). A version of the Model Ordinance was enacted in the city of Indianapolis. Indianapolis Code $\S 16-1$ et seq (1984). It was a challenge to the Indianapolis version that led to the American Booksellers Ass'n v Hudnut decision. See text accompanying note 11 .

- Model Ordinance at 141.

10 Id at 142.

11 American Booksellers Ass'n v Hudnut, 598 F Supp 1316 (S D Ind 1984), affd, 771 F2d 323 (1985), aff'd mem, 475 US 1001 (1986). 
images of women used in common advertising. ${ }^{12}$ Canadian novelist Margaret Atwood published The Handmaid's Tale, a bleak dystopian novel in which a movement aimed at suppressing pornography and violence against women led eventually to the governmental appropriation of the bodies of women for reproductive purposes and the enforcement of a harshly Puritanical code of sexual conduct, a code shaped and enforced by women but serving the needs of a totalitarian patriarchy. ${ }^{13}$ It was difficult not to read this powerful book as, among other things, a critique of the anti-pornography movement.

Some proponents of the ordinances berated their opponents for disloyalty to their gender. ${ }^{14}$ Scientists on whose work many had relied to support the claim that pornography's existence harms women claimed that they had been misrepresented; at best, they argued, their work shows a link between exposure to "violent" pornography and attitudinal changes that might lead to violent behavior toward women. ${ }^{15}$ In general, the atmosphere in which the pornography question was discussed became threatening and divisive. I suspect that many women who consider themselves feminists were relieved when the Supreme Court chilled discussion of the Model Ordinance approach by summarily affirming the Seventh Circuit's ruling that the Indianapolis version of that ordinance was unconstitutional.

Throughout all of this history, those who make and profit from pornography maintained a campaign to preserve their privilege to publish and sell materials without legal interference. The "industry," a shadowy and daunting network, relied on "moderate" organizations like the ACLU and the Playboy Foundation to continue to portray anti-pornography feminism as a threat to every-

\footnotetext{
12 See Feminist Anti-Censorship Task Force Appellate Brief Amici Curiae in American Booksellers Ass'n v Hudnut, 771 F2d 323 (7th Cir 1985) (Dkt No 84-3142, filed Apr 8, 1985), reprinted in Nan D. Hunter and Sylvia A. Law, Brief Amici Curiae of Anti-Censorship Task Force et al., 21 U Mich J L Ref 69 (1988) ("FACT Brief"). Indeed, Susan Faludi's popular book Backlash exposed the extent to which images of women in advertising were probably "pornographic" within the definition of the Model Ordinance. See Susan Faludi, Backlash 199 (Crown, 1991).

1s Margaret Atwood, The Handmaid's Tale 50-51, 152, 225-26, 273 (Ballantine, 1985).

14 See, for example, Catharine A. MacKinnon, Feminism Unmodified: Discourses on Law and Life 198-205 (Harvard, 1987); Dorchen Leidholdt, When Women Defend Pornography, in Dorchen Leidholdt and Janice G. Raymond, eds, The Sexual Liberals and the Attack on Feminism 125-31 (Pergamon, 1990).

1s Daniel Linz, Steven D. Penrod, and Edward Donnerstein, The Attorney General's Commission on Pornography: The Gaps Between "Findings" and Facts, 1987 Am Bar Found Res J 713, 721-22.
} 
one's freedom of speech. ${ }^{16}$ Feminists who dedicated themselves to contesting pornography's freedom to harm were labeled puritanical, ${ }^{17}$ moralistic, ${ }^{18}$ anti-sex, ${ }^{19}$ anti-love, ${ }^{20}$ fascist reactionaries. ${ }^{21}$ When a well-known constitutional law scholar expressed the view that the Model Ordinance was "not obviously unconstitutional," an equally well-known columnist suggested that the scholar's highly regarded mind had "turn[ed] to mush."22 Authors of such feminists classics as Our Bodies, Ourselves opposed the passage of anti-pornography ordinances because they feared the laws would be used to censor their work. ${ }^{23}$ Mainstream booksellers and authors were persuaded to denounce any efforts to control either the magnitude of pornography production or its increasingly violent content. ${ }^{24}$ Divided, exhausted, and confused, many feminists decided they would rather move on to other issues, of which there are, after all, many.

But others began considering and debating possible revisions to or variations on the MacKinnon-Dworkin ordinances, with an eye to finding a less-sweeping alternative. One result of these discussions was the Pornography Victims Compensation Act,

${ }^{16}$ See, for example, Dorchen Leidholdt, Introduction, in Leidholdt and Raymond, eds, The Sexual Liberals and the Attack on Feminism at xi-xii.

${ }_{17}$ See, for example, FACT Brief, 21 U Mich J L Ref at 69 (cited in note 12) (associating proponents of the Model Ordinance with the "sexual purity" movement).

18 Barbara Dority, Feminist Moralism, "Pornography," and Censorship, in Robert M. Baird and Stuart E. Rosenbaum, eds, Pornography: Private Right or Public Menace? 111, 112 (Prometheus, 1991).

10 De Grazia, Girls Lean Back at 586 (cited in note 3), quoting Hugh Hefner.

${ }^{20}$ See, for example, Allan Bloom, The Closing of the American Mind 103 (Simon and Schuster, 1987) ("[F]eminists are against [pornography] because it is a reminiscence of the old love relationship.").

21 De Grazia, Girls Lean Back at 617 (cited in note 3), quoting Anne Rice. But these were some of the nicer epithets. A correspondent of Playboy magazine characterized Catharine MacKinnon, for her persistence in pursuing the pornography issue after the Hudnut decision, as "the Freddy Krueger of the feminist movement." James R. Petersen, Catharine MacKinnon: again, Playboy 37 (Aug 1992). Perhaps the most bizarre suggestion was Wendy Kaminer's that anti-pornography forces consisted of "multiculturalists, poststructuralists, and advocates of traditional family values." Kaminer, Feminists Against the First Amendment at 110 (cited in note 7).

${ }_{22}$ De Grazia, Girls Lean Back at 613 (cited in note 3), quoting Nat Hentoff's comments on Laurence Tribe.

${ }^{23}$ See FACT Brief, $21 \mathrm{U}$ Mich J L Ref at 73-74 n 24 (cited in note 12) (Boston Women's Health Book Collective worked against Cambridge version of the Model Ordinance).

24 Writers joining the FACT Brief included Rita Mae Brown, Rosemary Daniell, Betty Dodson, Vivian Gornick, Carolyn Heilbrun, Del Martin, Kate Millett, Felice Picano, Minnie Bruce Pratt, Adrienne Rich, Alix Kates Shulman, Barbara Smith, and Ellen Willis. Other members of FACT include bookstore owners, editors, publishers, critics, and filmmakers. See id at 89-98. 
designed to "allow victims of sexual assault to sue distributors of obscene material or child pornography."25 Introduced in the Senate in 1991 by Senator Mitch McConnell of Kentucky, the bill was approved, in slightly different form, by the Judiciary Committee in 1992. ${ }^{26}$ The bill has some virtues, and also some serious defects; nevertheless, most of its critics ignored both and based their opposition on likening the proposal to the MacKinnon-Dworkin ordinance. They took note of the vast differences between the two only to minimize them, and characterized the new law as a warmed-over version of a measure already declared unconstitutional. ${ }^{27}$ It was argued in editorial pages across the nation that the bill was dangerous, ${ }^{28}$ it was argued with equal conviction that if passed, it would be completely ineffective. ${ }^{29}$ It was given the nickname "the Bundy Bill," ${ }^{30}$ and various critics seized on the suggestion conveyed by the nickname to argue that it would allow murderers and rapists to evade responsibility for their crimes. ${ }^{31}$ State lawmakers have not been entirely absent from the scene. In 1990, Illinois passed a civil liability statute that provides for civil suits by victims of sex crimes. ${ }^{32}$ Although not identical, it resembles the McConnell bill in enabling suits against distributors of obscene material. Massachusetts briefly considered passing a statute resembling the original MacKinnon-Dworkin Model Ordinance. ${ }^{33}$ One scholar has recommended the passage of legislation to enable feminists to bring

${ }^{25} \mathrm{~S}$ 1521, 102d Cong, 1st Sess, in 137 Cong Rec 10554 (July 22, 1991).

${ }^{26} \mathrm{~S}$ 1521, 102d Cong, 2d Sess, in 138 Cong Rec 12570 (Aug 12, 1992). For a history of the legislation, see Morrison Torrey, The Resurrection of the Anti-Pornography Ordinance, 2 Tex J Women \& L 113, 116 (1993).

${ }^{27}$ See, for example, Kaminer, Feminists Against the First Amendment at 110 (cited in note 7); Dezell, Bundy's Revenge at 15 (cited in note 7).

${ }^{28}$ See, for example, Dezell, Bundy's Revenge at 15; Willis, An Unholy Alliance at 78 (cited in note 7); Tom Teepen, Bill Poses Threat to Free Speech, Atlanta Journal \& Constitution A11 (Mar 31, 1992).

${ }^{20}$ See, for example, Kilpatrick, Well-Intentioned Pornography Bill at A1I (cited in note 7) (law is "all form and no substance").

so See Torrey, 2 Tex J Women \& L at $116 \mathrm{n} 17$ (cited in note 26) ("The Act is colloquially known as the 'Bundy Bill' after the convicted serial killer Ted Bundy, who made a statement on the eve of his execution that pornography had fueled his violent fantasies which he then acted out."); Dezell, Bundy's Revenge at 15; A Damaging Remedy, at A18 (cited in note 7).

${ }^{31}$ See, for example, Teepen, Bill Poses Threat at A11.

s2 720 ILCS 5/12-18.1 (1992). For a discussion of both the McConnell and Ilinois bills, see Torrey, 2 Tex J Women \& L 113; Thomas C. Palmer, Jr., A Bill of Divorcement: Women Are Split on Anti-pornography Law, Boston Globe 69 (Mar 29, 1992).

${ }_{33}$ Mass HB 5194, 177th Gen Ct, Reg Sess (Feb 28, 1992). See Tamar Lewin, Pornography Foes Push for Right to Sue, NY Times 16 (Mar 15, 1992); Torrey, 2 Tex J Women \& L 113 (cited in note 26). 
"group defamation" lawsuits against pornographers. ${ }^{34}$ These proposals are not ideal vehicles for the next stage of the anti-pornography debate-the McConnell bill and its Illinois relative are tied to the antiquated and preposterous definition of "obscenity" propounded by the United States Supreme Court over the years, ${ }^{35}$ and require as a precondition to the maintenance of the civil action that the pornographer and the perpetrator of the sex crime be convicted of crimes. In the case of the McConnell bill, it is unclear what advantage would be served by creating a federal cause of action for a matter that could be left to state tort law. As to the proposed Massachusetts law, it is doubtful that courts would find it any less unconstitutional than its ancestor. The "group libel" proposal would create a crime, an approach that might decrease the prevalence of pornography, but would leave individual victims without remedies. Nevertheless, the shortcomings of these particular pieces of legislation, and the criticism (both deserved and undeserved) they have received should not stall discussion of a more direct approach.

\section{A (Perhaps Excessively) Modest Proposal ${ }^{36}$}

It is difficult to go far in discussing pornography without defining it. I define "pornography" as material that links the viewer's or reader's sexual gratification to the infliction of violence. Pornography is a depiction, in any medium, of violence directed against, or pain inflicted on, an unconsenting person or a child, for the purpose of anyone's real or apparent sexual arousal or gratification, in a context suggesting endorsement or approval of such behavior,

34 See Jerome O'Callaghan, Pornography and Group Libel: How to Solve the Hudnut Problem, 27 New England L Rev 363 (1992). But others, including vigorous advocates of regulating pornography, deny that "group libel" is the most promising or appropriate characterization. See Catharine A. MacKinnon, Pornography as Defamation and Discrimination, $71 \mathrm{BU}$ L Rev 793, 807 (1991) ("The theory of group defamation does not adequately encompass the reality of pornography.").

${ }^{3 s}$ See, for example, Miller v California, 413 US 15, 24 (1972). Next to Catharine MacKinnon's observation that listening to the definition of obscenity sounds like hearing the Miranda warnings, Feminism Unmodified at 174 (cited in note 14), my favorite comment on this subject is Kathleen Sullivan's. She notes that the requirements that material must both "appeal to prurient interest" and "be patently offensive" in order to be obscene entail that the reader be simultaneously "turned on and grossed out." Kathleen M. Sullivan, The First Amendment Wars, New Republic 35, 38 (Sep 28, 1992). Not many judges or jurors, she suggests, "like to admit personally to being in such a double state." Id.

so It has become something of a tradition in regulation-of-speech scholarship to talk about modest proposals. See, for example, Nadine Strossen, Regulating Racist Speech on Campus: A Modest Proposal?, 1990 Duke L J 484; Carole S. Vance and Anne Barr Snitow, Toward a Conversation About Sex in Feminism: A Modest Proposal, 10 Signs 126 (1984). 
and that is likely to promote or encourage similar behavior in those exposed to the depiction. I do not intend to suggest this definition as legislative language, as I do not believe that legislation is necessary or desirable to enable litigation of victim-harm suits against pornographers. The definition is only a description of material that I think is vulnerable to civil sanctions. I also do not mean to suggest a definition that would preclude the use of other definitions in other contexts. ${ }^{37}$

Having offered this definition, I propose that persons claiming to have been "proximately" harmed by a particular piece of pornography should bring civil actions against the originators and distributors of the material. New legislation should not be necessary to enable such suits, as they are unexceptionable instances of personal liability litigation. It would be best if there were many such suits pending at any given time, if there were a virtual campaign of litigation that might spawn class actions, plaintiff's committees, the invocation of the "complex rules," 38 and other court-created management techniques. Techniques employed in other sorts of mass-tort litigation, such as epidemiological evidence ${ }^{39}$ and market-share liability, ${ }^{40}$ should be explored. First Amendment objec-

37 Elsewhere I have called this material the "new hard core," a term that appealed to me because it reflects the shift in interest away from sexual explicitness and toward harm. See Marianne Wesson, Sex, Lies and Videotape: The Pornographer as Censor, 66 Wash L Rev 913, 915 (1991). The Report of the Attorney General's Commission on Pornography used a similar definition (although broken down into three subcategories) for what it called sexually violent materials. US Department of Justice, Attorney General's Commission on Pornography, Final Report 323-24 (US GPO, 1986) ("Attorney General's Report").

${ }^{38}$ See Federal Judicial Center, Manual for Complex Litigation (Clark Boardman, 1978).

${ }^{39}$ See, for example, Pritchard v Liggett \& Myers Tobacco Co., 295 F2d 292, 296 (3d Cir 1961) (approving epidemiological studies together with other scientific evidence concerning smoking as a cause of cancer); Robinson v United States, 533 F Supp 320, 328 (E D Mich 1982) (analyzing epidemiological studies to hold against plaintiff); State Compensation Fund v Yazzie, 25 Ariz App 89, 90, 541 P2d 415, 416 (1973) (epidemiological evidence admissible to show radiation exposure caused cancer); In re "Agent Orange" Product Liability Litigation, 611 F Supp 1223, 1239-40 (E D NY 1985) (government epidemiological studies admissible). See generally Comment, Causal Inference in Epidemiology: Implications for Toxic Tort Litigation, 71 NC L Rev 247, 274-289 (1992); Michael Dore, A Commentary on the Use of Epidemiological Evidence in Demonstrating Cause-in-Fact, 7 Harv Envir L Rev 429 (1983); Khristine L. Hall and Ellen K. Silbergeld, Reappraising Epidemiology: A Response to Mr. Dore, 7 Harv Envir L Rev 441 (1983); Note, Proving Causation in Toxic Torts Litigation, 11 Hofstra L Rev 1299 (1983).

10 See Hymowitz $v$ Eli Lilly \& Co., 73 NY2d 487, 539 NE2d 1069, 1071-72 (1989) (adopting theory of market share liability in New York); Sindell $v$ Abbott Laboratories, 26 Cal 3d 588, 607 P2d 924, 937-38 (1980) (adopting theory of market share liability in California); Hardy v Johns-Manville Sales Corp., 509 F Supp 1353, 1356 (E D Tex 1981), rev'd on other grounds, 681 F2d 334 (5th Cir 1982) (granting discovery on theory of market share liability); Copeland v Celotex Corp., 447 S2d 908, 914-16 (Fla App 3d Dist 1984) (adopting 
tions undoubtedly will be made to any such suit as soon as it is filed, but these objections can be answered. The following section of this article suggests the form that the answer might take.

\section{The "R.A.V." Objection To Suits Against Pornographers}

Proponents of measures to deter and punish "hate speech" have often made common cause with proponents of measures to restrict pornography, and some see pornography as a subset of hate speech. The Supreme Court's recent decision in R.A.V.v City of St. Paul was thus disquieting to both groups-in its particular disapproval of the St. Paul measure to be sure, but also in its suggestion that even speech "unprotected" by the First Amendment may not be penalized if it was sanctioned because of its "viewpoint," rather than its other features. ${ }^{41}$

Since many of the measures proposed to penalize the creation and distribution of pornography are criticized for discriminating against pornography because of the "viewpoint" it espouses, ${ }^{42}$ it is important to understand certain nuances of the R.A.V. opinions.

market share liability in asbestos case). But see York v Lunkes, $189 \mathrm{Ill}$ App 3d 689, 545 $\mathrm{NE} 2 \mathrm{~d} 478,480$ (1989) (refusing to employ market share liability when product is not "fungible" as between manufacturers); In Re Related Asbestos Cases, 543 F Supp 1152, 1158 (N D Cal 1982) (refusing to adopt market share liability in asbestos cases because brands of asbestos not "fungible"). See generally David A. Fischer, Products Liability-An Analysis of Market Share Liability, 34 Vand L Rev 1623 (1981); Note, Market Share Liability: A Current Assessment of a Decade-Old Doctrine, 44 Vand L Rev 395 (1991); Note, Market Share Liability: An Answer to the DES Causation Problem, 94 Harv L Rev 668 (1981); Note, 11 Hofstra L Rev at 1302-06; Note, Market Share Liability and Asbestos Litigation: No Causation, No Cause, 37 Mercer L Rev 1115 (1986).

4112 S Ct 2538 (1992). The Court held unconstitutional a St. Paul ordinance that made it criminal to place on public or private property any symbol or graffito "which one knows or has reasonable grounds to know arouses anger, alarm, or resentment in others on the basis of race, color, creed, religion, or gender." Id at 2541.

${ }^{42}$ See Hudnut, 771 F2d 323, 332-33 (striking down MacKinnon-Dworkin Model Ordinance because it represented "viewpoint discrimination"). Although some have urged that pornography should not be considered speech at all, because its communicative content is small, see, for example, Frederick Schauer, Speech and "Speech"-Obscenity and "Obscenity": An Exercise in the Interpretation of Constitutional Language, 67 Georgetown L J 899 (1979), or should be considered low-value speech because it does not "amount to part of an appeal to deliberative capacities about public matters, or about matters at all," see Cass $R$. Sunstein, Neutrality in Constitutional Law (With Special Reference to Pornography, Abortion, and Surrogacy), 92 Colum L Rev 1, 23 (1992), others have argued that pornography carries a highly political message about the proper place of women in the polity. See, for example, Laurence H. Tribe, American Constitutional Law 924-25 (Foundation, 2d ed 1988); Geoffrey R. Stone, Anti-Pornography Legislation as Viewpoint-Discrimination, 9 Harv J L \& Pub Pol 461, 479-80 (1986); FACT Brief, 21 U Mich J L Ref at 119 (cited in note 12). Others make the point that pornography is objectionable and dangerous precisely because of the message-the highly political message-that it conveys. See Wesson, 66 Wash L Rev at 916 (cited in note 37). 
According to the majority, the St. Paul ordinance could not stand, even if it had been successfully "narrowed" to encompass only the unprotected category of "fighting words." Its flaw was that, even so narrowed, it would punish only a subcategory of "fighting words": those that had their effect "on the basis of race, color, creed, religion, or gender."43 This aspect of the ordinance rendered it "facially unconstitutional in that it prohibits otherwise permitted speech solely on the basis of the subject the speech addresses."44

The concurring opinions in R.A.V. exposed many gaps in the majority's reasoning-especially Justice White's concurrence, which observed that the majority acknowledged the existence of an exception to the general prohibition of discrimination among subcategories of unprotected speech, an exception so large as to swallow completely the rule it announced. ${ }^{48}$ Justices Blackmun and Stevens, also concurring, suggested that the Court had announced a rule that had no application beyond the case before it. ${ }^{46}$ It may be, therefore, that anti-pornography efforts have nothing to fear from R.A.V. because its purported rule was dead on arrival-fashioned (and perhaps even intended) to have no effect beyond its accompanying judgment. But it would be dangerous to assume so. As others have pointed out, the recent tradition on the

43 R.A.V., $112 \mathrm{~S} \mathrm{Ct}$ at 2542. A largely unremarked ambiguity in this language is only heightened by the narrowing construction given it by the Minnesota Supreme Court: does it mean that the actor must merely have had in mind an animus based on the race, gender, etc, of the victim (irrespective of the character of the fighting words), or does it mean that the words themselves must convey to the victim or to a reasonable victim, or be intended to convey to the victim, the existence and basis of the animus?

44 Id.

15 Id at 2552-53 (White concurring). Justice Scalia explained the exception as applying "[w] hen the basis for the content discrimination consists entirely of the very reason the entire class of speech at issue is proscribable." Id at 2545. He offered the exception to explain why it is constitutional for the federal government to punish threats against the President when it does not criminalize threats in general. The exception was said to apply to such a law because "the reasons why threats of violence are outside the First Amendment .. . have special force when applied to the person of the President." Id at 2546. But as Justice White suggested, it is equally plausible to argue that the reasons why "fighting words" are outside the First Amendment have special force when applied to groups that have historically been victims of discrimination. Id at 2556 (White concurring).

4 Justice Blackmun writes of the possibility that "this case will not significantly alter First Amendment jurisprudence but, instead, will be regarded as an aberration." Id at 2560 (Blackmun concurring). And Justice Stevens suggests that either the majority has held that "a government must either proscribe all speech or no speech at all," a result plainly inconsistent with numerous precedents, or that "the Court does not in fact mean much of what it says in its opinion." Id at 2562 \& $\mathrm{n} 1$ (Stevens concurring). 
Court, especially among some of the Jústices concurring in R.A.V., is one of respect for stare decisis. ${ }^{47}$

In addition, there are other reasons-beyond those provided by the concurring justices-why the decision in R.A.V. poses no constitutional threat to civil actions for damages. R.A.V. concerned the imposition of a criminal sanction. ${ }^{48}$ By contrast, the most similar civil cases to have faced a First Amendment challenge are defamation actions by private (that is, non-public figure) plaintiffs. In such cases, the First Amendment requires that the plaintiff prove some degree of fault in the media defendant, and some actual damage-but that is all. ${ }^{40}$

In connection with the implications of R.A.V., however, the most important feature of civil suits against pornographers as I envision them is that they are brought as just one of the many sorts of personal injury actions that can be brought under a jurisdiction's laws, requiring no specific statutory authorization. There is nothing "underinclusive," in the sense condemned by R.A.V., in the instituting or maintenance of such actions: they are not exclusive or limiting except in the trivial sense that any lawsuit is exclusive by claiming only what it claims and seeking only what it seeks, rather than claiming or seeking all of the other matters that might be claimed or sought under that jurisdiction's law. Of course, the definition of pornography that I offer is exclusive, in the sense that it does not include all sorts of speech or even all sorts of harmful speech. But the definition is offered to satisfy, rather than to offend, First Amendment constraints: to satisfy the requirement that there be a showing of fault on the part of the maker or distributor, and to define the type of damage that could foreseeably have been expected to flow from the pornographic material by its very nature. ${ }^{50}$ It excludes nothing. If another lawyer wishes to bring a different suit claiming that his client has been proximately harmed

\footnotetext{
17 See Daniel A. Farber, Foreword: Hate Speech After R.A.V., 18 Wm Mitchell L Rev 889, 894-95 (1992).

${ }^{13}$ See MacKinnon, Feminism Unmodified at 179 n 52 (cited in note 14). See also State v Mitchell, 485 NW2d 807 (Wis 1992), rev'd on other grounds as Wisconsin v Mitchell, 113 S Ct 2194 (1993). ("[T] here is a difference between the civil penalties imposed under . . . antidiscrimination statutes and [ ] criminal penalties . . . while the First Amendment may countenance slight incursions into free speech where the overarching concern is protection from objective acts of bigotry, ... the First Amendment will not allow the outright criminalization of subjective bigoted thought."). But see New York Times v Sullivan, 376 U.S. 254, 277-78 (1964) (First Amendment permits neither criminal nor civil sanction for false statements about public officials in absence of "actual malice").

19 Gertz v Robert Welch, Inc., 418 US 323, 347 (1974).

so See text accompanying notes $96-99$.
} 
by a violent but nonsexual film, a nonviolent advertisement for a weight control program, or a classified ad soliciting the commission of a crime, ${ }^{51}$ nothing in what I propose prevents such suits. (There may be something in the First Amendment to hinder them, but that is the other lawyer's problem and not mine).

\section{A First Amendment Defense of the Proposal}

Apart from any complications posed by $R . A . V$., the recognition and encouragement of victim actions against pornographers is consistent with the premises and aspirations of the First Amendment. Pornography is both speech and product. This double character has confounded the debate about the constitutionality of laws (actual or proposed) that would penalize the creation or dissemination of pornography. Those who emphasize the speech aspect point to the First Amendment and its prohibition against any law "abridging the freedom of speech." "52 "Those who find the product aspect more important sometimes propose that the protection of the public justifies a ban on the production or distribution of dangerous products, of which they argue pornography is one. They also argue that in the absence of a ban, those who sell pornography, like those who profit from other commercial products, should be liable for the harms their product causes. Sometimes there seems to be little ground for compromise between these two views, but in fact they share a commitment to a central model of free speech. Free-speech advocates often defend and elaborate the Constitution's protection of speech by reference to a concept borrowed from the world of products: the "marketplace of ideas." ${ }^{33}$ According to this theory,

s1 See text accompanying notes 64-71.

62 See, for example, FACT Brief, 21 Mich J L Ref at 100 (cited in note 12). It is a familiar observation, of course, that the First Amendment contains no such absolute prohibition, but rather permits the outright suppression of some sorts of speech and the imposition of penalties on other forms. See, for example, MacKinnon, Feminism Unmodified at 208 (cited in note 14); Wesson, 66 Wash L Rev at 924 (cited in note 37).

53 The most famous expression of this notion is in Justice Holmes's dissent in Abrams $v$ United States, 250 US 616, 630 (1919) (Holmes dissenting). As others have observed, it borrows from Milton's Areopagitica the idea that truth cannot be "put to the worse in a free and open encounter." John Milton, Areopagitica, in George H. Sabine, ed, John Milton: Areopagitica and Of Education 50 (Harlan Davidson, 1951). The Supreme Court has consistently reinforced its own use of this metaphor. See, for example Board of Education v Pico, 457 US 853, 866 (1984); Citizens Against Rent Control/Coalition for Fair Housing $v$ City of Berkeley, 454 US 290, 295 (1981); Widmar $v$ Vincent, 454 US 263, 267 n 5 (1981); Columbia Broadcasting System v Democratic Nat'l Comm., 412 US 94, 189 (1973) (Brennan and Marshall dissenting). Defenders of free speech invoke the marketplace reflexively. See, for example, Kenneth L. Karst, Equality as a Central Principle in the First Amendment, $43 \mathrm{U}$ Chi L Rev 20, 25 (1975) ("The advancement of knowledge depends on 
the world of thought, analysis, emotion, and contemplation that is expressed by speech is best protected by fostering a "marketplace" in which all speech (and hence all expressible ideas, emotions, opinions, and the like) may be offered to the would-be recipient, who is free to listen or not, and to believe or not. Thus the discriminating consumer of speech will make choices based on the quality and persuasiveness of the marketplace's offerings, and in the end the better, truer, and more beautiful speech will survive. One who accepts this model will also accept another First Amendment cliche: that the cure for bad speech is more speech. ${ }^{54}$ Law-andeconomics-school analysts and public choice theorists employ essentially the same analysis-seeing the marketplace for speech as similar to the marketplace for other products. ${ }^{\mathrm{ss}}$

There are of course many things wrong with this metaphor, most of which are obvious even from reading the rendition above. As feminists and others have pointed out, there are many ways in which the so-called "marketplace of ideas" does not at all resemble a marketplace, or at best resembles a very flawed one. One problem is what economists call "barriers to entry": not everyone who would like her ideas to be heard can afford to buy time on network television. A.J. Liebling, speaking for an earlier era, observed that "[f]reedom of the press is guaranteed only to those who own one." ${ }^{\text {"S6 }}$ Ross Perot is sufficient evidence, in this electronic age, of this remark's lasting relevance. The metaphor's depiction of governmental censorship as an interference with universal access to the channels of communication may be apt, but it ignores the censoring effect of poverty (or anything less than affluence), or illiteracy. Another related shortcoming of the marketplace model is that

unfettered competition between today's prevailing opinions and those opinions that may come to prevail tomorrow."). It is the dominant paradigm invoked by the courts and by civil libertarians. See, for example, Stanley Ingber, The Marketplace of Ideas: A Legitimizing Myth, 1984 Duke L J 1, 2-3.

s4 Whitney v California, 274 US 357, 375 (1926) (Brandeis concurring) ("[T]he fitting remedy for evil counsels is good ones."). But see Toni M. Massaro, Equality and Freedom of Expression: The Hate Speech Dilemma, 32 Wm \& Mary L Rev 211, 218 (1991) (characterizing this sentiment as a "bromide"); Charles R. Lawrence III, If He Hollers Let Him Go: Regulating Racist Speech on Campus, 1990 Duke L J 431, 476 (characterizing it as an "empty ideal").

${ }^{35}$ See Richard A. Posner, Economic Analysis of Law 627 (Little, Brown, 3d ed 1986) ("Ideas are a useful good produced in a highly competitive market. The marketplace of ideas of which Holmes wrote is a fact, not merely a figure of speech."); Daniel A. Farber, Free Speech Without Romance: Public Choice and the First Amendment, 105 Harv L Rev 554 (1991).

so Richard Kluger, The Paper: The Life and Death of the New York Herald Tribune 341 (Knopf, 1986). 
it does not account for the "silencing" effect of some speech: the speaker with the loudest amplifier may make it impossible for listeners to sample the words or sounds of alternative speakers, or one speaker may capture the market by discouraging his listeners from listening to others. Some feminists have claimed that pornography has this silencing effect on the voices of women, especially when they wish to speak of sexuality and equality. ${ }^{.77}$ But even if the "marketplace" of ideas is flawed in these ways, its flaws will be magnified if pornography is insulated from the discipline the marketplace imposes on other products. I propose, therefore, to inquire into what follows if one accepts the civil libertarian and utilitarian view of speech as a market.

I will argue that this "market" view entails not only tolerating, but affirmatively insisting on, the right of pornography's victims to sue its creators for damages when a causal link between the pornography and the damage may be established. This proposition may be surprising, since civil libertarian groups and speakers have consistently opposed not only bans on producing or distributing pornography, but also the creation of any tort remedies for those who are harmed by it. ${ }^{58}$ Nevertheless, the necessity of such remedies is implicit in the free marketplace theory of the First Amendment.

It is a fundamental feature of an efficient marketplace that it be free of externalities, ${ }^{89}$ where an externality is the imposition of some cost to a transaction on someone other than the parties. ${ }^{60}$ Air pollution is an externality to the transaction of producing, purchasing, and using an automobile, and a perfect market would require that the cost of preventing or cleaning up the pollution generated by an automobile be built into the transaction-whether by requiring that all vehicles have expensive anti-pollution equip-

${ }^{87}$ See Susan Griffin, Pornography and Silence: Culture's Revenge Against Nature 1-2 (Harper \& Row, 1981); MacKinnon, Feminism Unmodified at 181 (cited in note 14); Wesson, 66 Wash L Rev at 934-36 (cited in note 37). For more general critiques of the marketplace theorists, see Ingber, 1984 Duke L J I (cited in note 53); Cass R. Sunstein, Free Speech Now, 59 U Chi L Rev 255 (1992).

${ }^{88}$ See notes 27-28 and accompanying text. See also Nadine Strossen, A Feminist Critique of "The" Feminist Critique of Pornography, 79 Va L Rev 1099, 1188-90 (1993) (letter from Feminists for Free Expression to Senate Judiciary Committee opposing Pornography Victims Compensation Act).

s9 See Richard A. Posner, Economic Analysis of Law 254 (Little, Brown, 4th ed 1992) ("[T]he most dramatic economic function of the common law is to correct externalities."); Burton A. Weisbrod, Public Interest Law: An Economic and Institutional Analysis 10, 289 (California, 1978).

so See Weisbrod, Public Interest Law at 10, 289. 
ment, imposing a tax on each sale, or some other stratagem (such as taxing each gallon of gasoline sold or collecting tolls for the use of roads). In the absence of some accounting for the cost of pollution, the cost is borne by all who breathe (if no mitigation measures are taken) or all who pay general taxes (if they are undertaken by the government); in its absence as well, manufacturers and sellers of vehicles have no economic incentive to minimize pollution, nor have purchasers any economic incentive to favor (or certainly to pay more for) vehicles that pollute less. Economic analysts agree virtually unanimously that a rational market must force producers of polluting vehicles to internalize the cost of the pollution their vehicles will produce-otherwise, air pollution and its harms will increase to the detriment of all, including those who have no interest in and derive no benefit from the transaction. ${ }^{61}$ Economic injustice will certainly result, and perhaps overall economic inefficiency, since it is possible that the overall cost of air pollution exceeds the marginal economic benefit gained from manufacturing and driving vehicles that create it (rather than non-polluting vehicles).

Thus if the transaction that encompasses the creation, distribution, and consumption of pornography is one that creates a serious external harm, the logic of the marketplace dictates that the pornography industry should internalize the harm. A tax on pornography is neither feasible nor efficient, since arguments are certain to arise about whether or not particular items are "pornography"62 and various pornographic materials almost certainly differ in the harm they cause. But if outsiders to the transaction (that is, women and others who can show they have been harmed by pornography) can recover compensation for the harm the transaction imposes on them, those who profit from the transaction will bear the cost; the harm will be internalized. Pornography will become more expensive to produce as those who traffic in it must set aside funds to pay for anticipated damage awards, or to purchase insurance. Those who do not take these precautions may be forced to go out of business if a large award consumes their operating capital. The price of pornography will rise, and it may consequently attract

61 See id at 14, 292; Frank J. Vandall, Strict Liability: Legal and Economic Analysis 22-23 (Quorum, 1989).

62 On defining "pornography," see text accompanying note 37. 
fewer customers. Its remaining creators may decide to stop disseminating it. This is not censorship-it is the market at work. ${ }^{63}$

\section{The Market At Work: Recent Cases}

Some readers may doubt that courts will ever be persuaded to treat speech like a product and subject it to the discipline of the market. But consider the recent case Soldier of Fortune $v$ Braun. ${ }^{64}$ Soldier of Fortune is a magazine, published in my hometown of Boulder, Colorado, devoted to the cult of manly mercenary violence. In addition to articles about survivalism, weapons, and its writers' adventures in various world hotspots, the magazine at one time published classified advertising. In one of these ads Michael Savage advertised his willingness to accept work requiring "[b]odyguard, courier, and other special skills" (although he promised "[a]ll jobs considered"); among his qualifications he listed " 37 year old professional mercenary," "Vietnam Veteran," and "[d]iscrete ${ }^{65}$ and very private." Among those responding to the ad were Bruce Gastwirth and Horton Moore, who had failed in three previous attempts to murder Gastwirth's business partner Richard Braun and apparently had decided they needed professional assistance. Gastwirth and Moore enlisted Savage's help, and within three months of the day the ad first appeared in Soldier of Fortune, Braun was dead-murdered by a man named Doutre, apparently assisted by Savage. The attack also injured Braun's teen-age son Michael.

Michael Braun and his brother filed a civil action against Soldier of Fortune seeking damages for the death of their father (under Georgia's wrongful death action) and for the injuries inflicted on Michael. A federal jury awarded the Brauns two million dollars in compensatory damages on their wrongful death claim, and $\$ 375,000$ in compensatory and ten million dollars in punitive damages for Michael Braun's personal injury claim. ${ }^{66}$ On appeal, Soldier of Fortune argued that the First Amendment prohibits the imposition of damages (particularly such "crushing" damages) on publishers, but the Court of Appeals for the Eleventh Circuit rejected this argument, and the Supreme Court denied certiorari. Distinguishing this case from an earlier one in which the Fifth Cir-

\footnotetext{
${ }^{63}$ For a similar argument, focused primarily on defamation but applicable to pornography, see Frederick Schauer, Uncoupling Free Speech, 92 Colum L Rev 1321, 1326-24 (1992).

${ }_{64} 968$ F2d 1110 (11th Cir 1992), cert denied, 113 S Ct 1028 (1993).

6s The Court of Appeals inserted "[sic]" at this point.

${ }_{68}$ The punitive damages were later reduced to two million dollars in remittitur.
} 
cuit had overturned a jury verdict on similar facts, the Court of Appeals noted that the Braun jury had found that the "ad in question contained a clearly identified unreasonable risk, that the offer in the ad is one to commit a serious violent crime."67 The court also rejected Soldier of Fortune's argument that it could not be held responsible for independent acts of a third party. The court observed that Georgia law, like that in most American jurisdictions, ${ }^{68}$ allows for liability of an original tortfeasor when an independent actor's conduct intervenes in the causal chain, if the acts of the intervening party were foreseeable. ${ }^{60}$ The Supreme Court's refusal to review the outcome of Soldier of Fortune $v$ Braun suggests that violent pornography, if defined as that which implicitly but unmistakably advocates directing sexual violence against women, can be the subject of a civil suit for damages without violating the First Amendment.

It may be objected that the Braun suit is different from the sort of civil action advocated by anti-pornography feminists, because advertisements (including classified ads) are "commercial speech" and hence deserve less First Amendment protection than speech which is the product itself, not merely an advertisement for it. It is true that the Court of Appeals treated the Soldier of Fortune ad as "commercial speech," and noted that such speech has diminished First Amendment protection. ${ }^{70}$ But other courts have upheld damage awards for injuries caused by speech that was more in the nature of "the thing itself" than of an advertisement for it. Defamation of a private individual, for example, is actionable if it is false and the publisher is negligent about that fact. ${ }^{21}$

Or consider Weirum v RKO General, Inc., brought by the survivors of a man killed when his automobile was forced off a highway by a pair of cars. ${ }^{72}$ The teen-age drivers were listening to a radio broadcast that continuously gave clues to the location of a disc jockey who was driving around the region, and were attempting to locate the deejay in order to win a prize offered by the radio station. A jury found the radio station liable for the death of the

67 Braun, 968 F2d at 1118, 1119-20 \& n 10.

6 W. Page Keeton, ed, Prosser and Keeton on Torts 301-19 (West, 5th ed 1984).

$968 \mathrm{~F} 2 \mathrm{~d}$ at 1122.

70 Id at 1118-19.

11 Gertz v Robert Welch, Inc., 418 US 323, 347 (1974).

72123 Cal Rptr 468, 539 P2d 36 (1975). According to the court, one or the other of the teen-age drivers forced the decedent off the road. 539 P2d at 39. One of the insurers settled the plaintiffs' claim, and a trial jury returned a verdict against the other driver, together with the radio station. Id. 
deceased, and the California Supreme Court rejected the station's First Amendment argument as "clearly without merit," commenting that " $[t]$ he First Amendment does not sanction the infliction of physical injury merely because achieved by word, rather than act." T3 The broadcast was not an advertisement, but was the speech itself. Yet those responsible were made to bear their share of liability for the harm caused as surely as those responsible for Soldier of Fortune's ad.

Of course, in neither Braun nor Weirum were the defendants' words the immediate cause of the plaintiffs' injuries. The words did not fly out and strike the victims, killing or injuring them. Rather, they encouraged or enabled others to inflict the death or injury, whether intentionally or accidentally. This pattern is often observed in product liability and negligence suits, where many necessary causes may intervene between the creation of the risk and the victims' injuries: a person is attacked by an individual under the influence of a dangerous prescription drug; ${ }^{74}$ a driver is injured when a dump truck with defectively designed brakes, driven carelessly, collides with her car. ${ }^{75}$ It has never been the rule that the intervening acts of a third party will inevitably cut off the liability of the person who created the risk (although intervening actors may share the liability and may be made, through various mechanisms, to contribute to a judgment against the original tortfeasor). In such cases, to impose liability on the original tortfeasor, a court must find that she or he should have foreseen the risk that some intervening actor might behave in the manner that caused the plaintiff's harm.

Notice that no special legislation concerning liability for classified advertising or radio promotional contests was necessary to the results in Braun or Weirum. The outcomes of these cases merely represented the application of principles governing other product liability or negligence lawsuits. These suits are approved by most economic analysts of the law, because they contribute to the formation or maintenance of efficient markets. Products that are likely to cause harm must internalize the costs of the harm-either by investing in measures designed to prevent it (for example, mak-

73 Id at 40 . The court also rejected the station's argument that it should not be held responsible for harm caused by the intervening negligent acts of another. This argument fared no better under California law here than it did under Georgia law in Braun. See text accompanying notes 68-69.

${ }^{74}$ Jeannelle $v$ Thompson Medical Co., 613 F Supp 346 (E D Mo 1985). 1973).

${ }_{75}$ Bradford v Bendix-Westinghouse Automotive Air Brake Co., 517 P2d 406 (Colo App 
ing the Pinto crashworthy, at least for the sorts of crashes that it is likely to encounter), or by shouldering the cost of the harms to which it contributed. Those who persist in committing harmful speech acts may eventually find it very difficult to stay in business, but they are not compelled by any governmental agent to stop running classified ads placed by ambitious thugs or broadcasting invitations to drive like maniacs. Perhaps it would be better if they were, but the First Amendment does not permit that result. The same result may, however, be achieved over time by operation of tort law, about which the First Amendment has much less (but not nothing) to say. ${ }^{76}$

It is true that there are cases in which the First Amendment has shielded the creators or publishers of speech that would have generated tort liability, but for that shield. In Olivia $N . v$ National Broadcasting Company, for example, the plaintiff was deprived of any recovery when the defendant's broadcast of the rape of a girl with a "plumber's helper" was found to have caused a group of boys to rape the plaintiff using the same method. ${ }^{77}$ The California Court of Appeal found that the First Amendment required this result, and the Supreme Court denied certiorari. In Herceg $v$ Hustler Magazine, Inc., no recovery was allowed when a teenaged boy hanged himself, apparently while seeking to achieve an autoerotic experience described in detail (together with the method of achieving it and a "warning" that the reader should not attempt the practice) in the defendant's publication. ${ }^{78}$ The Court of Appeals reversed a judgment of $\$ 169,000$ in favor of the boy's mother on First Amendment grounds, ${ }^{79}$ and the Supreme Court again denied certiorari. ${ }^{80}$ In Eimann $v$ Soldier of Fortune, the Fifth Circuit overturned a multimillion dollar verdict in favor of survivors of a murder victim whose husband had hired an assassin from the classified ads of Soldier of Fortune magazine, and the Supreme Court refused review. ${ }^{81}$ The lawyer who would represent the pornography victim must contend with these precedents, but they do not pose insuperable obstacles.

78 Compare Derrick Bell, Foreword: The Final Civil Rights Act, 79 Cal L Rev 597 (1991) (in which Bell's alter ego Geneva Crenshaw proposes a law permitting, but taxing heavily, racial discrimination).

${ }_{77} 126$ Cal App 3d 488, 178 Cal Rptr 888 (1981), cert denied as Niemi v National Broadcasting Company, 458 US 1108 (1982).

78 814 F2d 1017 (5th $\mathrm{Cir}$ 1987).

79 Id at $1019,1025$.

${ }^{80} 485$ US 959 (1988).

s1 880 F2d 830 (5th Cir 1989). 
The Olivia $N$. court suggested the outcome might have been different if the program's depiction of the assault were an "incitement" to commit a similar crime. ${ }^{82}$ Although the court hinted that proof of "incitement" would require a showing that the defendant intended to encourage the behavior, ${ }^{83}$ an alternative interpretation of that term would encompass any implication that the broadcaster, writer, or filmmaker approves of the conduct depicted. Under this interpretation, the sort of suit I have suggested would be consistent with the First Amendment, since my definition of pornography includes only those materials that depict sexualized violence in a context that implies approval of the same, and is likely to encourage others to engage in it. ${ }^{84}$

In Herceg, the plaintiff's attorneys premised their arguments on appeal entirely on the theory that Hustler had incited Herceg's experiment with autoerotic asphyxiation, abandoning their other claims. ${ }^{85}$ The court did not find enough evidence of "incitement" as it understood the term, in part because Hustler had included a "warning" that its readers should not attempt the practice it described, and in part because there was no proof that the article's encouragement created an "imminent" danger. Although the dissenting opinion is certainly right in criticizing the majority's fanatically wooden application of the categories generated by the Supreme Court's First Amendment cases, ${ }^{88}$ Herceg can be distinguished as a case in which the plaintiff did not attempt to articulate a theory of liability beyond that of "imminent incitement to lawless action." In Eimann, the plaintiff's verdict was overturned because the advertisement was held to be ambiguous as a matter of law, and because the jury instructions suggested that

\footnotetext{
82 The trial judge had nonsuited the plaintiff at the close of her counsel's opening statement because the lawyer had disclaimed any evidence that the defendant had "incited" the conduct that victimized his client. Olivia $N$., $126 \mathrm{Cal}$ App $3 \mathrm{~d}$ at 491.

${ }^{83}$ Id at 495 (Incitement means "directed to inciting or producing imminent lawless action and . . . likely to incite or produce such action."). The court used the notion of "incitement" to distinguish Weirum, arguing that in that case there was "incitement" of the listeners, see Weirum, 539 P2d at 48, but nothing in the appellate opinion in Weirum suggests the existence of any evidence that the radio station wanted or desired its listeners to drive recklessly.

st See text accompanying note 37 . This limitation is included in the definition to exclude depictions designed to arouse the viewer's sympathy, pity, horror or anger without implying the originator's approval of the conduct depicted.

8s 814 F2d at 1019.

${ }^{86}$ See id at 1025-30 (Jones concurring in part and dissenting in part). The majority observes, for example, on the strength of the facts of Brandenburg v Ohio, 395 US 444 (1969), that "the root of incitement theory appears to have been grounded in concern over crowd behavior." 814 F2d at 1023.
} 
Soldier of Fortune had a duty to investigate the "context" of the ad. ${ }^{87}$ The court did not rest its holding on the defendant's First Amendment arguments, and the eventual outcome of Braun $v$ Soldier of Fortune confirms Einmann's limited reach. ${ }^{88}$

\section{Complexities of Causation and HaRm}

In any suit of the sort I suggest, the plaintiff's attorney must address two different types of causation. One is a general causal relation between pornography (defined as I have suggested) and violent harm to persons, and the other is the particular causal relation between certain pornographic material produced or distributed by the defendant and the harm suffered by the plaintiff. The second of these tasks is, of course, one that must be undertaken by any plaintiff's attorney in any personal injury lawsuit. ${ }^{80}$ The congeries of doctrines known collectively as the law of proximate cause is both complex and uncertain, ${ }^{80}$ but no more so in this sort of case than in many others. The intervening agency of a third party (the rapist, the assailant, the one who forces pornography on the victim) does not defeat proof of a causal relationship between the pornographic material and the harm, if some such harm was foreseeable by the pornographer-defendant. ${ }^{\text {11 }}$ This last qualification suggests the relationship between this particular causation requirement and the more general requirement of proving that pornography causes harm. As more and more research seems to affirm that exposure of men to violent sexual material leads to harm to women, ${ }^{92}$ and as this research and its conclusions are publicized and discussed, it will become more and more difficult for creators and dealers of pornography to claim they did not foresee that their activities would lead to harm. It will become correspondingly more likely that juries and judges will accept the arguments of victims that the risk of their injury-or the sort of injury they suf-

87 880 F2d 830 (5th Cir 1989). See also the discussion of Eimann in Braun, 968 F2d at $1115-16$

8880 F2d at 836 .

so Keeton, ed, Prosser \& Keeton on Torts at 263 (cited in note 68) ("An essential element of the plaintiff's cause of action for negligence, or for that matter any other tort, is that there be some reasonable connection between the act or omission of the defendant and the damage which the plaintiff has suffered.").

so See Mark Kelman, The Necessary Myth of Objective Causation Judgments in Liberal Political Theory, 63 Chi Kent L Rev 579 (1987).

91 Keeton, ed, Prosser and Keeton on Torts at 301-19.

${ }^{92}$ See text accompanying notes $96-99$. 
fered-was known to the defendant, or would have been known to him had he been reasonably prudent.

The general causation requirement also performs an independent function in such a lawsuit by reassuring the judge, who in its absence would harbor a First Amendment-generated solicitude for the defendant's conduct. In civil suits seeking damages for injuries proximately caused by speech, courts have traditionally assuaged their concerns about the speech-inhibiting character of a plaintiff's recovery by observing that the defendant's speech was known to be likely to cause harm..$^{93}$ Whether phrased as an aspect of negligence or causation, evidence of the reasonably prudent defendant's knowledge that his speech-act risks harm to another is an integral ingredient of the plaintiff's case. ${ }^{94}$ Hence my definition of pornography has a built-in foreseeability element: "Pornography is a depiction . . . likely to promote or encourage similar behavior in those exposed to the depiction."9s

I do not think that many plaintiff's attorneys will fail to produce evidence of a general causal link between exposure to violent pornography and harm to women. Although some researchers have been reluctant to affirm the existence of a link between exposure to nonviolent sexual material and harmful changes in the subject's attitudes or thoughts, those who have done the most work in this area acknowledge that exposure to materials that depict the infliction of pain or rape does have such a damaging effect. After a series of disputes about what they did and did not find, and whether their work had or had not been misused by anti-pornography forces, ${ }^{96}$ researchers Daniel Linz and Edward Donnerstein clarified their views as follows:

Researchers have documented that men who view sexually violent materials in controlled situations may demonstrate increased callousness toward women. The men undergo several attitudinal and perceptual changes, tending to see a rape vic-

${ }^{93}$ See, for example, Braun, 968 F2d 1110 (approving a "modified negligence" standard for publishers of classified advertisements); Beauharnais v Illinois, 343 US 250, 253 (1952).

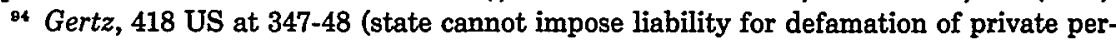
son in absence of fault); Brandenburg, 395 US 444, 450-53 (Douglas concurring) (collecting cases) (damages for "clear and present danger" speech must be foreseeable to be recoverable).

os See text accompanying note 37.

${ }^{88}$ Compare Attorney General's Report at 299-351, 901-1035 (cited in note 37) (relying on Donnerstein's work to show harm of pornography), with Linz et al, The Gaps Between "Findings" and Facts (cited in note 15) (complaining that the Commission misused their work). 
tim presented to them later as less injured and more responsible for her assault. The men are also more likely to endorse myths such as the idea that women secretly enjoy sexual assault. ${ }^{97}$

Linz and Donnerstein emphasize, however, that these findings do not suggest a relationship between exposure to nonviolent sexually explicit material and any such attitudinal changes; indeed, they claim that it is the violence of the material rather than the explicitness of its sexual content that makes it dangerous. "Slasher" films, they say, are more likely to have harmful effects than some X-rated materials..$^{98} \mathrm{I}$ believe that my definition of pornography, "a depiction ... . of violence directed against, or pain inflicted on, an unconsenting person or a child, for the purpose of anyone's real or apparent sexual arousal or gratification," captures the essence of the materials that have been documented as likely to lead to harm. Note that the definition does not exclude materials that depict the unconsenting victim as later grateful for being hurt or raped. Such depictions are among the most infuriating to feminists, and for a good reason; research suggests that such "positive outcome" depictions of sexualized violence are among the most dangerous in inducing dangerous attitudinal or behavioral changes in those exposed to them. ${ }^{99}$

Many have argued that pornography is harmful to women in more subtle and important ways than the positivistically proximate harm-inducing respect that would generate a successful lawsuit under my proposal. ${ }^{100} \mathrm{I}$ do not disagree with the claims of those who argue that pornography (here used in a much broader sense) harms women in ways that the clumsy drama of a lawsuit cannot expose or compensate. As MacKinnon says,

Instead of [a] more complex causality . . . the view became that pornography must cause harm the way negligence causes car accidents or its effects are not cognizable as harm. The trouble with this individuated, atomistic, linear, isolated, tortlike-in a word, positivistic-conception of injury is that the

97 See Daniel Linz and Edward Donnerstein, Research Can Help Us Explain Violence and Pornography, Chronicle of Higher Education B3 (Sep 30, 1992).

98 Id.

99 See Edward Donnerstein, Daniel Linz, and Steven Penrod, The Question of Pornography: Research Findings and Policy Implications 160 (Free Press, 1987); Diana Scully, Understanding Sexual Violence: A Study of Convicted Rapists 55-58 (Unwin Hyman, 1990).

${ }^{100}$ See, for example, Susan Griffin, Pornography and Silence at 3 (cited in note 57). 
way pornography targets and defines women for abuse and discrimination does not work like this. ${ }^{101}$

I also do not disagree with the claims of MacKinnon and others who argue that pornography (again, used in a broader sense) does not just cause harm to women, it is harm to women. ${ }^{102}$ I do not doubt the power of speech and ideas to force identities onto women that we have not chosen, yet find impossible to contest. However, I do doubt whether a legal system that protects hate speech that causes harm of a similar sort ${ }^{103}$ will be persuaded to uphold the prohibition of pornography because of the reality that it constructs. But I do not propose a limit on what should "count" as a cognizable legal harm.

The real source of disagreement here is less about causation than about harm-about what counts as harm in the legal system. It is true that many of the harms women encounter in their daily lives do not "count" in lawsuits or criminal codes because they are invisible, incomprehensible, or just uninteresting to those whose interests constructed the law. ${ }^{104}$ It is also true that inspired lawyering can sometimes make those harms visible and illegal-that is, can both "out" and "outlaw" them. ${ }^{105}$ Although I doubt the success of lawsuits predicated on a woman's emotional distress at being perceived or constructed as less than fully human, the law of personal injury sometimes recognizes harms to the psyche. ${ }^{108}$ From the obvious case of the woman who is raped by a man to the accompaniment of a pornographic videocassette, to the far more

102 MacKinnon, Feminism Unmodified at 156 (cited in note 14).

102 See, for example, Richard Delgado and Jean Stefancic, Pornography and Harm to Women: "No Empirical Evidence?", 53 Ohio St L J 1041, 1048 (1992) ("[P]ornography is a per se harm, namely that of being derogatorily constructed as passive, hypersexual, masochistic, a sexual plaything, and so on.") (emphasis added).

${ }^{203}$ See R.A.V., $112 \mathrm{~S}$ Ct 2538.

${ }^{104}$ For the best description, see generally Robin L. West, The Difference in Women's Hedonic Lives: A Phenomenological Critique of Feminist Legal Theory, 3 Wis Women's L J 81 (1987). See also Cynthia Grant Bowman, Street Harassment and the Informal Ghettoization of Women, 106 Harv L Rev 517, 518-20 (1993).

105 Catharine MacKinnon and others have proven this with their work on sexual harassment. See Catharine A. MacKinnon, Sexual Harassment of Working Women xi (Yale, 1979); Lin Farley, Sexual Shakedown: The Sexual Harassment of Women on the Job (McGraw-Hill, 1978). Their view was eventually adopted by the courts. See, for example, Meritor Savings Bank $v$ Vinson, 477 US 57, 73 (1986) (recognizing sexual harassment as a form of illegal sex discrimination).

Other once-invisible harms that the legal system has (in some places) come to acknowledge through the efforts of law reformers and litigators are marital rape, see State $v$ Smith, $85 \mathrm{NJ} \mathrm{193,} 426 \mathrm{A2d} \mathrm{38,} 39$ (1981), and domestic violence. See, for example, Simmons $v$ Simmons, 773 P2d 602, 603-04 (Colo App 1988).

${ }^{108}$ Keeton, ed, Prosser and Keeton on Torts at 54-56 (cited in note 68). 
challenging case of a woman who feels imprisoned in her home after dark because of the clientele of the adults-only bookstore on the corner, it must be left to the ingenuity, resourcefulness, and eloquence of the attorneys in such cases to convince the judges and juries that there has been real harm and legally compensable injury.

Happily, one need not prove "causation" in these cases to the satisfaction of a philosopher, ${ }^{107}$ for the law's rules on causation are not really rule-like, and are amenable to manipulation. ${ }^{108}$ From the standpoint of a critical legal theorist this is a bad thing, ${ }^{109}$ but for the proposal I make here, it is a blessing. I understand that there is a continuous "background" exposure to sexualized violence against women in print, on television, in advertising, and in movies. I also appreciate the difficulty in separating the causal contribution of this continuous background effect from that of any particular piece or pieces of pornography. Nevertheless, I believe most jurors would be horrified and disgusted by the sort of violent pornography that this proposal targets. I believe further that their reaction would lead them, where there is any evidence of a causal contribution, to resolve doubt in favor of finding a causal connection between a particular piece of pornography and any harm to a victim they find believable and appealing. In the same way, jurors are often willing to find that exposure to a particular carcinogen caused a worker's cancer, even against a background of toxic exposure experienced by all and despite defense arguments about the confounding of causality that it occasions. ${ }^{110}$

\section{OTHer OBJections CONSIDERED}

I anticipate other objections to the campaign of personal injury litigation that I suggest. Some will argue that placing liability for the injuries of raped or assaulted women on pornographers will create at least a psychological escape from responsibility, or even a legal defense, for the criminal who immediately committed the

\footnotetext{
${ }^{207}$ I thank my friend Alison Jagger for educating me on the difficulty of this enterprise. The writings of Professor Frederick Schauer also promoted my appreciation of certain difficulties. See, for example, Frederick Schauer, Causation Theory and the Causes of Sexual Violence, 1987 Am Bar Found Res J 737 (discussing meaning of causal conclusions in the Attorney General's Report).

${ }^{108}$ See, for example, Kelman, 63 Chi Kent L Rev 579 (cited in note 90); Mark Kelman, Interpretive Construction in the Substantive Criminal Law, 33 Stan L Rev 591 (1981).

${ }^{109}$ See Kelman, 33 Stan L Rev 591.

110 See, for example, Elam v Alcolac, Inc., 765 SW2d 42, 185-87 \& n 63 (Mo App 1988).
} 
crime. ${ }^{111}$ I cannot say I understand the psychology of violent criminals well enough to address the first possibility, although Diana Scully's work suggests that the opposite may be true-that it is the availability and prevalence of pornography, in the absence of any public suggestion that the scenes it depicts are wrong or objectionable, that assuages whatever qualms the would-be sexual criminal might otherwise experience. ${ }^{112}$ In any event, the second concern is not necessary. The law of solicitation allows for the guilt of both the solicitor and the solicitee; that of complicity, for the guilt of both the encourager and the actor. Both negligence and products liability law recognize that two or more parties may be liable to an individual for harm caused by the joint operation of their conduct. To the extent the sexual criminal wishes to identify a particular piece or pieces of pornography as having inspired his crimes, he will find himself no less guilty. He may nevertheless wish to do so, either to identify another party to share civil liability or for other reasons, and by doing so will provide me with a partial answer to another objection I anticipate.

This next objection I conceive as the opposite of "If you build it, they will come."113 That is, it will be objected that even if lawsuits such as I describe would be heard by courts, and could overcome First Amendment obstacles, no one will bring them-because of the poverty of the likely plaintiffs, the uncertainty of recovery, and the difficulty of identifying the source of the pornography. ${ }^{114} \mathrm{I}$ concede these difficulties, especially the last. Unless there is some "signature" or other circumstance to suggest a sex criminal's inspiration by a particular work of pornography, there may be insuperable proof difficulties. As suggested above, however, the criminal himself may disclose the identity of his despicable Muse. Moreover, I would expect resourceful plaintiff's attorneys to find ways to deal with these difficulties, as did resourceful plaintiff's attor-

11 See, for example, Damaging Remedy at A18 (cited in note 7).

112 Scully, Sexual Violence at 100-17 (cited in note 99). Close to half of the group Scully studied were "deniers" who, despite having been convicted and quite apart from any attempt to shift the blame to pornography, continued to claim they had not raped their victims. Scully found that the principal source of this claim was their exposure to images of women as whores, as teases, as creatures who don't know their own minds and say no when they mean yes-that is, the sorts of images of women found in pornography. Id.

113 From the film Field of Dreams, this mysterious phrase gives the hero to understand that he should build a ballpark, and that if he does so dead baseball players will come to life and compete there. He does and they do, of course. It says a great deal about some baseball fans that they did not find this film sappy.

114 This objection has been raised to the Pornography Victims Compensation Act. See Kilpatrick, Well-Intentioned Pornography Bill at A11 (cited in note 7). 
neys in the asbestos litigation, where most of the stricken plaintiffs had no idea who had manufactured the particular asbestos product to which they were exposed. ${ }^{115}$

A further objection, one that has been raised to almost every proposal designed to discourage pornography, is that we need education, not litigation. But the two do not exclude one another and may converge in important respects. Litigation has played an enormous educative role in this country's history, concerning issues from desegregation to sexual harassment to rape to employment discrimination. Moreover, entire research industries emerge once issues become legal issues. When one's entitlement to certain legal benefits depends on whether.she suffers from a "learning disability,"118 learning disability experts begin to appear. When lawsuits begin to claim that exposure to high-intensity electromagnetic fields may cause cancer or miscarriages, studies are done. When DNA evidence begins to be admitted in criminal cases, labs begin to tool up to do that kind of work. There has been some work on the causes of sexual violence (both in general and in particular cases), but there needs to be more. Similarly, recognizing lawsuits against pornographers will encourage research into the effects of pornography.

I also anticipate the objection that a proposal such as mine will inevitably be turned in the first instance against feminist speech. Such a fear animated the writers of the FACT brief, and was expressed by many in the debate over the Model Ordinance. ${ }^{117}$ Audre Lorde's observation that "the Master's tools will never dismantle the Master's house" captures the reservations of many feminists toward strategies that would award a male-dominated legal system a role in controlling violence against women. ${ }^{118}$ But I do not believe that Lorde meant to caution against using any maleoriginated power against continuing male dominance and violence; such a universal caution would have discouraged enforcement of the Civil Rights Act of 1964 (including those provisions later held to prohibit sexual harassment), the reform of rape laws, the prose-

\footnotetext{
115 See Note, 11 Hofstra L Rev 1299 (cited in note 39); Sindell, 607 P2d 924.

${ }^{116}$ See Americans With Disabilities Act, 42 USC §§ 12101-213 (1990); 28 CFR § 35.104 (1991); 29 CFR \& 1630.2(h)(2) (1992).

${ }_{127}$ See Robin Morgan, Theory and Practice: Pornography and Rape, in Laura Lederer, ed, Take Back the Night: Women on Pornography 137 (Morrow, 1980); Anna Gronau, Women and Images: Toward a Feminist Analysis of Censorship, in Varda Burstyn, ed, Women Against Censorship 91 (Douglas \& McIntyre, 1985).

${ }_{118}$ Audre Lorde, The Master's Tools Will Never Dismantle the Master's House, in Audre Lorde, Sister Outsider 110-13 (Crossing, 1984).
} 
cution of domestic violence. I cannot conceive, moreover, of any speech that I would call "feminist" that would fit within the definition of pornography used here-the depiction of unconsented sexual violence in a context implying approval of the same and likely to encourage the observer to do the same, that is to inflict unconsented violence. I have read the arguments of lesbians and others who value sadomasochistic sexual experiences ${ }^{119}$ and I do not understand them to argue for the value of speech that encourages nonconsensual violence.

Finally, I expect this proposal to be criticized because it offers too little. Catharine MacKinnon has said that individual lawsuits by victims of pornography can never amount to more than a mopping-up operation. ${ }^{120}$ This may be true, metaphorically speaking. But others criticized MacKinnon and Dworkin's Model Ordinance on the ground that in a world full of male violence, combatting pornography was a task with very small potential for good ${ }^{121}$-in other words, a mopping-up operation. What I propose will not save women from the use of rape as a political weapon in Bosnia, will not heal the wounds of incest victims in Illinois or Colorado, probably will not eliminate pornography, even violent pornography. It's mopping up, but women are good at that. When I visualize the Master's tools, mops are not among them. If we wield them well, we may well dismantle a part of his house.

119 See, for example, Paula Webster, Pornography and Pleasure, in Kate Ellis et al, eds, Caught Looking (Real Comet, 1986); Barbara Ehrenreich, Elizabeth Hess, and Gloria Jacobs, Re-making Love: The Feminization of Sex (Anchor, 1986); Linda Williams, Hard Core: Power, Pleasure, and the "Frenzy of the Visible" (California, 1989); Pat Califia, Sapphistry (Naiad, 1981).

120 MacKinnon, Feminism Unmodified at 204 (cited in note 14).

121 See, for example, Ann Snitow, Retrenchment Versus Transformation: The Politics of the Antipornography Movement, in Varda Burstyn, ed, Women Against Censorship 107 (cited in note 117); Lisa Duggan, Nan Hunter, and Carol S. Vance, False Promises: Feminist Antipornography Legislation in the U.S., in Burstyn, ed, Women Against Censorship 130 (cited in note 117). 